\title{
Indonesian Intelligence Reform: Recent Challenges and Opportunities for Encouraging Democratic and Professional Intelligence
}

\section{Mufti Makarim A.}

Executive Office of the President of the Republic of Indonesia, https://ksp.go.id/en/index.html

\begin{abstract}
This article describes the dynamics of Indonesia's intelligence reform from combatant intelligence posture during the post-independence revolution of 1945 to the authoritarian state intelligence under the New Order regime after 1965, and to the era of intelligence reform after the 1998 reformation movement. Recently, the challenges for Indonesian intelligence institutions have shifted from the need for legislation and political policies to the need for a democratic intelligence posture and the ability to face emerging security threats. Another challenge is the sectoral rivalry between the military, police, and strategic intelligence services, all of which are oriented towards internal security threats and domestic intelligence operations. Domestic threats form a contested operational domain, a 'grey' zones of defense, security, and intelligence threats.
\end{abstract}

Keywords: intelligence reform, military, Orde Baru, Soeharto, BIN, Covid19, pandemic.

\section{Introduction}

"For Your Eyes Only" 1

On July 3, 2020, President Joko Widodo (Jokowi) signed the Peraturan Presiden (Presidential Decree, Perpres) Number 73 of 2020 concerning the Coordinating Ministry for Political, Legal and Security Affairs (Kementerian Koordinator Bidang Politik Hukum dan Keamanan, Kemenkopolhukam). Interestingly, this Presiden-

1 Inscription on the Entrance of the State Intelligence Agency (BIN) Office, South Jakarta. 
tial Decree eliminates the coordinating function of the Ministry regarding the Badan Intelijen Negara (State Intelligence Agency, BIN), which has been regulated in Presidential Decree Number 43 of 2015. Thus, the President is the only user and direct 'manager' of all operations and institutions of this Indonesian strategic intelligence agency.

The public trauma from extraordinary intelligence 'powers' - especially military intelligence-permitting control of the public sphere and the political system has not completely disappeared yet. In a country that has experienced 32 years of authoritarian of the Orde Baru (New Order) rule (1965-1998), the arrangement of all intelligence elements in government agencies and ministries remains an important issue. For the generation who experienced the socio-political atmosphere in that era, a strict and non-tolerant position towards distortions of authority and primary duties and functions of intelligence is absolute, non-negotiable.

One of the factors causing the extraordinary strategic intelligence 'power' was the full control of intelligence by President Soeharto during the Orde Baru era. Without a democratic system of checks and balances and the formation of an oligarchic government supported by military forces and businessmen, cronies of the rulers, President Soeharto used intelligence to promote not only the interests of state security but also his own and his family's political and economic interests.

"The return" of the President's full control over BIN has brought back memories and concerns about the potential for 'misuse' of intelligence for the government's political interests. Especially in the midst of the current momentum of the Covid-19 pandemic, where the President has the authority to take fast, unpopular, and emergency political and policy steps, including the deployment of military and intelligence forces to support efforts to deal with the threat of the Covid-19 pandemic. Concerns were raised regarding the function of BIN as a tool for the political interests of the President.

The government rejected this issue and allegation. "BIN is directly under the President because the President directly needs intelligence products," stated Mahfud MD, Coordinating Minister for Political, Legal, and Security Affairs, on his official Twitter on 18 July 2020. ${ }^{2}$ This is in accordance with the principle of the President being the single client of BIN. Although officially removed from coordination under Kemenkopolhukam, Mahfud emphasized that his ministry could still ask BIN for information. "As a minister, I always get information from the Head of BIN and often ask BIN to give presentations at ministerial meetings," he said. ${ }^{3}$

This article will briefly retrace the history of Indonesia's strategic intelligence dynamics since its inception and provide an analysis of the current status of po-

2 See https://nasional.kompas.com/read/2020/07/20/09300611/kini-di-bawah-presidenini-sejarah-singkat-bin?page=all.

3 See https://nasional.kompas.com/read/2020/07/19/11344241/bin-tak-lagi-di-bawahkemenko-polhukam-ini-penjelasan-mahfud-md. 
litical democratization in general and intelligence reform in particular after 1998. The article will respond to concerns over the backflow of democracy with the full control of the president over BIN. The views expressed here are purely personal and are not related to the opinions or attitudes of any government agencies. ${ }^{4}$

\section{Intelligence after the 1945 Proclamation of Independence}

The history of Indonesian intelligence parallels the history of the independence revolution after the Proklamasi Kemerdekaan (Proclamation of Independence) on August 17, 1945. The intelligence agents' talents that were 'scattered' among the Japanese military-educated youths in 1943 were consolidated into a strategic intelligence force, whose primary mission was to defend the independence from an attack by the Allied forces and the Dutch who wanted to regain control of Indonesia.

Zulkifi Lubis, born in Banda Aceh on 26 December 1923, a military officer who was the Chief of Staff of the Army in 1955, is considered the 'founder' of Indonesia's strategic intelligence, currently known as BIN. Lubis is a graduate of the Nakano Military Intelligence School founded by the Japanese occupation in 1943 [in Tangerang city, Banten province] and is the best graduate of the school's first class. With 40 former soldiers of Pembela Tanah Air (Homeland Defenders, PETA), formed by the Japanese Military, in August 1945, Lubis ran the first intelligence agency of the Republic of Indonesia called the Badan Istimewa (Special Agency). ${ }^{5}$

Lubis had experience in intelligence operations since his early graduation from the Nakano Military Intelligence School. In 1944 he was stationed at Japan's Regional Intelligence Center in Singapore. He studied a lot and participated in Japanese intelligence operations in the Greater Asia war of conquering Indochina. So, when Indonesia became independent in August 1945, Lubis, who was 19 years old when he was recruited for intelligence school, became one of the Indonesian ex-Japanese militaries who had more combat intelligence experience than anyone in Indonesia. This new country needed an intelligence capability to defend its independence, which is reflected in the name of the Badan Istimewa. The initial 40 members of this agency, all of whom were alumni of the Japanese military, were trained quickly by Lubis to master the principles of intelligence, psychological warfare, and sabotage. Then they were dispatched to all regions

4 Studies on Indonesian intelligence reform divide the dynamics of intelligence into four periods, namely: 1) Period in support of military operations (1945-1958); 2) Period supporting the implementation of political policy (1959-1965); 3) Period in favor of regime sustainability; and 4) Period of support to restoration of security. See Ali A. Wibisono, "Reformasi Intelijen dan Badan Intelien Negara (Intelligence Reform and State Intelligence Service)," in Panduan Pelatihan Tata Kelola Sektor Keamanan untuk Organisasi masyarakat Sipil: Sebuah Toolkit (Security Sector Governance Training Guide for Civil Society Organizations: A Toolkit), ed. in Mufti Makaarim A., et al. (IDSPSDCAF, 2009), 11.

5 See http://www.bin.go.id. 
of the island of Java with the mission to seek support to defend the Republic and oversee the enemy's movements. ${ }^{6}$

In early May 1946, special training was conducted in the Ambarawa city [Central Java province] area for newly recruited agents. As a result, about 30 young graduates became the first batch members of the Badan Rahasia Negara Indonesia (Indonesian State Secret Agency, BRANI). This agency became the 'umbrella' for the Intelligence movement with several ad hoc units, including units for overseas operations. ${ }^{7}$ BRANI was formed by Lubis on May 3, 1946, as an umbrella organization for the ad hoc units formed by field commanders and spread throughout Java. Lubis also moved outside Java by ship to form field units in Bali, Kalimantan, Maluku, Nusa Tenggara, Sulawesi and Sumatra. Lubis himself raised funds and resources to carry out operations abroad, to garner support for the republican army that was short on weapons, ammunition, and medicine. ${ }^{8}$

The civilian-controlled Ministry of Defense proposed to President Soekarno to form a strategic intelligence organization with a "civil character," which did not come under the auspices of the military. In July 1946, defense minister Amir Sjarifuddin tried to create a "Badan Pertahanan B" (Defense Office B) headed by a former police commissioner. Then he unified all intelligence agencies under the Ministry of Defense on April 30, 1947. Despite President Soekarno's support, BRANI was eventually disbanded and changed to Bagian V (Part V) of Badan Pertahanan B. Bagian V [also called KP V] as a "small unit" of Badan Pertahanan B that could not work optimally. Upon the fall of Sjarifuddin from the Cabinet, $B a-$ gian $V$ was dissolved, and Lubis carried out an intelligence 'purge' of members of the Partai Komunis Indonesia (Indonesian Communist Party, PKI) who Sjarifuddin had recruited. The "Madiun Rebellion" in 1948, which was crushed by the military, resulted in the arrest and silent execution of Sjarifuddin. ${ }^{9}$

When Amir Sjarifuddin's Cabinet fell in January 1948 [a few months before the Madiun rebellion], the government included the disbanded Intelligence $B a$ gian $V$ as an element in the Bagian I Staf Umum Angkatan Darat (Part I of the General Staff of the Army, SUAD). Lubis was back to be the leader and concurrently the head of the Markas Besar Komando Djawa (Java Command Headquarters, MBKD-I). After the transfer of sovereignty from the Netherlands, the intelligence organization became the Intelijen Kementerian Pertahanan (Ministry of

6 See Ken Conboy, Intel Menguak Tabir Dunia Intelijen Indonesia (original title: Intel Inside Indonesia's Intelligence Service) (Pustaka Primata, 2008), 1-2. For the English Edition see Ken Conboy, Intel Inside Indonesia's Intelligence Service (Equinox Publishing, 2004). See also https://historia.id/militer/articles/zulkifli-lubis-bapak-int Cerdasindonesia-DrBXE.

7 See http://www.bin.go.id. BRANI is spelled similarly to to Indonesian word 'berani' (brave or bold).

8 Conboy, Intel Inside Indonesia's Intelligence Service, 3-5.

9 Conboy, Intel Inside Indonesia's Intelligence Service, 7-8. See also Hariyadi Wirawan, Evolusi Intelijen Indonesia (Evolution of Indonesian Intelligence), in Reformasi Intelijen Negara (Reform of State Intelligence), ed. Andi Widjajanto (Pacivis UI-FES, 2005), 2829. 
Defense Intelligence, IKP), with Lubis remaining as its head. Lubis then formed the Biro Informasi Angkatan Perang (Armed Forces Information Bureau, BISAP) in 1952, which was in charge of preparing strategic information for the Minister of Defense and the Chief of Staff of the Armed Forces, General TB Simatupang. He also initiated further education for intelligence which took place in Kaliurang, Yogyakarta Province. ${ }^{10}$ BISAP itself was considered sub-optimal in carrying out its strategic intelligence function, one of the factors being Lubis' 'feud' with General $\mathrm{AH}$ Nasution, ${ }^{11}$ the top leader of the Army, so that Lubis had to deal more with the military "internal politics."

In the same year, Vice President Mohammad Hatta and Minister of Defense Sri Sultan Hamengku Buwono IX accepted an offer from the United States Central Intelligence Agency (CIA) to train Indonesian professional intelligence candidates on Saipan Island, the Philippines. ${ }^{12}$ This tacit US assistance was organized through the Bureau of Security or Dinas Chusus (DC) - the ministry-equivalent body that coordinated Ministry of Defense operations, and not through BISAP, which the Vice President and Minister of Defense considered 'unreliable.' Thus, the Bureau of Security compiled a roster of 50 civilians to compete in Central Java, and 17 of them were the first to attend this training. In February 1953, they returned to Indonesia and found many changes. BISAP had been disbanded, Army Chief of Staff General AH Nasution - who was Lubis' "mortal enemy" - was fired by President Soekarno, ${ }^{13}$ Lubis was appointed as Deputy of Kepala Staf

10 See Hendri F. Isnaeni, "Zulkifli Lubis, Bapak Intelijen Indonesia," Historia, February 2, 2016, https://historia.id/militer/articles/zulkifli-lubis-bapak-intelijen-indonesia-DrBXE.

11 Nasution is a designer of the Dwifungsi ABRI (Angkatan Bersenjata Republik Indone$\mathrm{sia}^{\prime}$ ) or Dual-function of Armed Forces of the Republic of Indonesia which was delivered in 1958 and later adopted during the Soeharto administration. This concept is a way for ABRI not to be under civilian control, but at the same time not to dominate so that it becomes a military dictatorship. On 17 October 1952, Nasution [and General Simatupang] mobilized their troops to encircle the Presidential palace to protest civilian interference in military affairs, and aimed the cannon muzzle at the palace. Sukarno out of the Presidential Palace to meet the demonstrators and finally convinced both the soldiers and civilians to return home. The aftermath of this incident was $\mathrm{Na-}$ sution's dismissal in December 1952. On 7 November 1955, after three years of exile, Nasution was re-appointed to his old position as Kepala Staf Angkatan Darat (Army Chief of Staff), and Lubis was displaced.

12 See http://www.bin.go.id.

13 Another version states that the 17 October incident [as the first open conflict between the army and civilian politicians] was triggered by a session of the Dewan Perwakilan Rakyat Sementara (Provisional People's Representative Council, DPRS) which discussed the modernization of the Army, which was considered to be their internal authority under the leadership of Nasution and Simatupang. On 17 October 1952, officers from the Army Headquarters together with several regional commanders went to the Palace to meet President Sukarno, asking him to take power and dissolve the Provisional Parliament. Sukarno did not give in to military pressure and Nasution, as the top officer of the army headquarters, resigned afterwards. See Kisenda Wiranatakusumah, Civil-Military Relations in the Late Suharto Era, Thesis (Naval Postgraduate School, 2000), 17-21. 
Angkatan Darat (Chief of Staff of Army); and after BISAP was disbanded, all military services included and operated their respective intelligence organizations. The Security Bureau installed these Saipan alumni in the Ksatria Graha (Ksatria Firm). They run intelligence operations under the Security Bureau. ${ }^{14}$

On December 5, 1958, President Soekarno formed the Badan Koordinasi Intelijen (Intelligence Coordinating Board, BKI) and appointed Colonel Pirngadi as its head. This agency aimed to rearrange the coordination between all the scattered elements of intelligence to consolidate the President's power, who had to deal with rebellions and attacks by civilian and military opposition. Furthermore, on November 10, 1959, BKI became the Badan Pusat Intelijen (Central Intelligence Agency, BPI), headquartered at Jalan Madiun Jakarta and headed by Dr. Soebandrio, who was also the Minister of Foreign Affairs and a trusted confidant of the President. During the 1960s and until the end of the Orde Lama (Old Order) era, Soebandrio's influence on the BPI was very strong in the wake of the war of Communist and non-Communist ideology in the military, including the Intelligence. ${ }^{15}$

By November 1965, BPI became a 'tool' in the battle of Subandrio's interests, linked to the claim to protect President Soekarno from the planned coup of the Dewan Jenderal (General Council of the Army). Allegations of collaboration between the Army and American and British intelligence to overthrow President Soekarno, who was considered to be protecting the PKI and "making political space" for the party, were flatly rejected by the Army's leadership. On September 30, 1965, seven Army officers in Jakarta and two in Central Java became victims of the "30 September Movement" attacks. The ability of the military to take control quickly after this event was the "end to the political career of Subandrio and the PKI." The Army's counterattack was carried out under the command of Major General Soeharto based on the Surat Perintah 11 Maret (Order of 11 March 1966, Supersemar) from President Soekarno to "restore security," which included a provision for cleaning up BPI.

The Army "took over" BPI, appointing Brigadier General Sugiharto as acting chief of BPI in December 1965. Earlier in November, he was promoted to be Chief of Army Intelligence, replacing Brigadier-General Siswondo Parman, one of the officers killed in the September 30 kidnapping incident. Between 18 and 21 March 1966, several high-ranking BPI officials considered PKI sympathizers were arrested and sentenced to prison. Subandrio himself was tried and sentenced to death (he was imprisoned, but the sentence was never carried out).

Theoretically, the type of Intelligence-State interaction formed in this period is "Political Intelligence." Even during 1950-1959, Indonesian intelligence activities did not receive much attention due to the relatively volatile political conditions. After the Republic of Indonesia was officially recognized on August 15, 1950, the intelligence agencies in Indonesia were reactivated. Indonesia had to

14 Conboy, Intel Inside Indonesia's Intelligence Service, 9-14.

15 See http://www.bin.go.id. 
direct intelligence operations to deal with internal threats. However, the dominance of militarization in the previous period led to the construction of political intelligence only in 1958 when Sukarno formed BKI, which was later changed to BPI. In 1950-1958, military intelligence still dominated the operational activities of the intelligence services, even though they were not directed to face a specific external threat. This politicization process began in early 1952 when the Chief of Staff of the Armed Forces TB Simatupang formed BISAP as an intelligence agency to support his office and the Defense Ministry. However, due to its structural marginal position and limited resources and funds, BISAP could not do much and was dissolved in the following year. ${ }^{16}$

\section{Orde Baru (New Order) Intelligence 1965-1998 ${ }^{17}$}

Major General Soeharto was put in charge of the Komando Operasi Pemulihan Keamanan dan Ketertiban (Operation Command for Restoring Security and Order, KOPKAMTIB), formed three days after the "September 30 Movement" attacks. He took decisive actions to restore security and 'clean-up' the sympathizers and PKI members, including those in the intelligence circle. Soeharto, who really understood the importance of the intelligence function and the need to move quickly, formed the Satuan Tugas Intelijen (Intelligence Task Force, STI) in all regions under the Komando Daerah Militer (Regional Military Command, KODAM). STI was a support operation for KOPKAMTIB led by all KODAM Commanders to carry out investigations and perform other intelligence activities.

The structure of the guerrilla warfare in the post-1945 independence war, which divided the territory of Indonesia into military command areas, was adopted as a manifestation of Nasution's "middle way" concept to meet the military needs of 'eradicating' the PKI and holding political control as a form of Dwifungsi ABRI. At every level of civilian government, there is a military element included in a forum called the Musyawarah Pimpinan Daerah (Council of Regional Leadership, Muspida), usually led by elements from the military. This arrangement has survived to this day (see Table 1). In most cities and provinces, Governors and mayors are appointed by President and usually are ABRI officers. ${ }^{18}$ The definite advantage Soeharto gained from this activation of territorial commands was the degree of power and military intelligence operations that the structure could carry out, which kept Suharto 'updated' with "any threat" even from the village level.

16 See Andy Widjajanto and Artanti Wardhani, State-Intelligence Interaction 1945-2004 (Pacivis UI \& FES, 2008), 70-71.

17 Soeharto administration called his period as Orde Baru (New Order) as a replacement of President Soekarno era's that he called as Orde Lama (Old Order).

18 See Salim Said, Soeharto's Armed Forces: Problems of Civil Military Relations in Indonesia (Pustaka Sinar Harapan, 2006), 20-22. 
Table 1. Parallel Civil Bureaucracy and Army Territorial Command. ${ }^{19}$

\begin{tabular}{|l|l|}
\hline \multicolumn{1}{|c|}{ MILITARY STRUCTURE } & CIVIL ADMINISTRATION \\
\hline KODAM (as Regional Military Command) & Province \\
\hline KOREM (as Sub-Regional Military Command) & Residency \\
\hline KODIM (as District Military Command) & District \\
\hline KORAMIL (as Sub-District Military Command) & Sub-District \\
\hline $\begin{array}{l}\text { BABINSA (as Village Development Non-Commis- } \\
\text { sioned Officer) }\end{array}$ & Village \\
\hline
\end{tabular}

On August 22, 1966, with support from President Sukarno, Suharto established the Komando Intelijen Negara (State Intelligence Command, KIN) with Brigadier-General Yoga Sugomo in the lead. The head of KIN is directly responsible for reporting to Soeharto. As a strategic intelligence agency, BPI, which was already under the Army's control, was merged into KIN which also had Operasi Khusus (Special Operations, Opsus) under Lieutenant Colonel Ali Moertopo with assistants Leonardus Benyamin (LB) Moerdani ${ }^{20}$ and Aloysius Sugiyanto. ${ }^{21} \mathrm{KIN}$ was a new agency reporting on national and international security issues, including political, social, economic, and other matters related to military security at home and abroad. Soeharto led this institution himself in his early days, placing his confidants in key positions. Less than a year later, on May 22, 1967, when Suharto officially became President, he issued a Keputusan Presiden (Presidential Decree, Keppres) to designate KIN as the Badan Koordinasi Intelijen Negara (National Intelligence Coordinating Board, BAKIN). Major General Soedirgo became the first head of BAKIN. Like in KIN, the upper echelon included predominantly military officers, although the middle and lower levels were also filled with civilian bureaucrats. BAKIN was designed as a civilian institution. However, in reality, top military officers retained strong control over BAKIN.

19 See Said, Soeharto's Armed Forces, 22.

20 Moerdani is known as a military officer who has been involved in the intelligence activities a lot, so his figure is often considered mysterious. Moerdani was directly involved in the military operation handling the hijacking of Garuda Indonesia Flight 206 at Don Mueang Airport, Bangkok, Thailand on March 28, 1981, an event that was later documented as the first plane hijacking in Indonesian airline history and the first act of jihadist terrorism in Indonesia. He is also considered by many as the figure responsible for the Tanjung Priok incident (the attack on a mosque congregation) and the mysterious shootings in the 1980s when hundreds of people who were considered criminals were found dead on the streets. In a government position, apart from serving as ABRI Commander in 1983-1988, he also served as Minister of Defense and Security and also Commander of KOPKAMTIB.

21 August 22 is celebrated as the anniversary of KIN, which is currently BIN, http://www.bin.go.id. 
Apart from being known as the military order, the Orde Baru was marked by the permeation of intelligence of all aspects of people's lives. BAKIN became a strategic intelligence operation vehicle for all issues, apart from KOPKAMTIB, which carried out the purge of the PKI and its sympathizers through the military territorial Command structure and the STI. Opsus, which was initially an intelligence operation aimed at seizing West Papua from the Netherlands and enabling the confrontation with Malaysia, was later mobilized to spy on social, political, and religious life in society, especially individuals and groups that could potentially oppose the Soeharto government, as well as to conduct intelligence operations facing the threat of separatism in Aceh, Papua, and East Timor. ${ }^{22}$ Thus, the military bodies attached to the civilian government ultimately carried out an intelligence 'function' to guard against what the Orde Baru called latent dangers and security threats. In this context, cases of violence and human rights violations occurred massively, reversing the socio-political dimension (e.g., limiting the space for expression, arresting and killing political activists or opposition leaders) as well as the social and cultural economy, e.g., by forced taking of people's land and destruction of the environment and forests 'escorted' by military and intelligence organizations.

Soeharto's strategy in the 1970s was to create 'contestation' between institutions so that they could never 'unite' against Suharto, who ended up placing all intelligence agencies under his direct control. Even though Soeharto designated BAKIN as a strategic intelligence agency, he did not immediately disband KOPKAMTIB and Opsus. Soeharto also 'strengthened' the figure of the "Intelligence Assistant" under the Ministry of Defense and Security who was expected to direct concurrently the ABRI's (Commander of the Armed Forces of the Republic of Indonesia) controlled territorial military intelligence units, KOPKAMTIB, and BAKIN, which often ran overlapping operations and even competed with the aim of securing Soeharto's interests. Moerdani, who was entrusted with leading the Strategic Intelligence Center under the Ministry of Defense and Security when he was appointed Commander of ABRI in January 1983, formed the Badan Intelijen Strategis (Strategic Intelligence Agency, BAIS) and built an international network by controlling defense attaches in Indonesia's Embassies. With large

22 Moerdani, who had experience as Intelligence Assistant to the Minister of Defense and Security, Assistant Intelligence to the Commander of KOPKAMTIB, Head of the Pusat Intelijen Strategis (Strategic Intelligence Center, Pusintelstrat), and Deputy Head of BAKIN, was deeply involved with the issue of the decolonization of East Timor. In August 1975, Moerdani began sending Indonesian soldiers under the guise of volunteers to infiltrate East Timor. The situation intensified on November 28, 1975, when Fretilin declared the independence of East Timor. Intelligence operations ceased and the military operation, Operasi Seroja (military invasion]) was initiated instead. Although Seroja was not an intelligence operation, Moerdani continued to be involved, this time as an invasion planner and the person behind of intelligence component of the operation. 
budget support and a strong network at home and abroad, BAIS eventually became the intelligence agency that stood out and outperformed other agencies. ${ }^{23}$

BAIS itself has been criticized for establishing a one-sided perception of what a national security threat constitutes by making civilians from various critical groups a threat. By using the term to identify groups in conflict with the Pancasila ideology-the official state ideology as stipulated by the constitution-BAIS divides the sources of the threat into the following categories:

1) Left radical groups: those who have a social-democratic or communist/ Marxist political orientation;

2) Right radical groups, namely those in political organizations that promote the discourse of Islamic law; and

3) Other radical groups, namely NGOs that are dissatisfied and disappointed with the government, such as Imparsial and KontraS (two out of dozens of Indonesian NGOs campaigning for human rights and security sector reform). ${ }^{24}$

Soeharto-Moerdani's relationship became increasingly tenuous towards the end of the 1980s. Soeharto, who was aware of the emergence of international and national political pressures on the issue of democracy, changed his strategy to safeguard his power by 'embracing' the Islamic groups that he managed to raise in the Ikatan Cendikiawan Muslim Indonesia (Indonesian Muslim Intellectuals Association, ICMI). Soeharto automatically developed a new 'green' ABRI style to eliminate the impression of his anti-Islamic attitude. Under ABRI Commander General Faisal Tanjung - a Muslim and loyalist of Soeharto, appointed in May 1993-BAIS was disbanded and changed to the Badan Intelijen ABRI (ABRI Intelligence Agency, BIA) with many personnel changes to erase Moerdani's influence in the Indonesian intelligence world. ${ }^{25}$ At BAKIN, Suharto deliberately appointed Lieutenant General Moetojib, a TNI officer who was not too influential and did not disobey. While BAIS attempted to mobilize Islamic groups by creating a combination of military-intellectual Muslim elites at ICMI, BAKIN's orientation shifted to monitoring pro-democracy movements and political activists who increasingly opposed Suharto's rule in the 1990s. ${ }^{26}$ Previously, in 1988, along with Moerdani's descent, KOPKAMTIB was also changed to the Badan Koordinasi dan Stabilitas Nasional (National Stability and Coordination Agency, Bakorstanas). Moerdani's footsteps immediately disappeared.

23 See Aleksius Jemadu, "State Intelligence Agency," in 2007 Security Sector Reform Almanac, ed. Beni Sukadis (Lesperssi-DCAF, 2007), 92-93. See also Widjajanto and Wardhani, State-Intelligence Interaction, 79-93.

24 See Rizal Darma Putra, "Strategic Intelligence Agency (BAIS)," in 2007 Security Sector Reform Almanac, 106-107.

25 See Salim Said, Soeharto's Armed Forces, 86.

26 Jemadu, "State Intelligence Agency," 93. 


\section{Intelligence Reform Era after 1998}

When Soeharto 'resigned' from his post as President in May 1998 at the pressure of the political pro-democracy movement and a decrease in support of the civilian political elite, his successors could not immediately make radical changes to the structure and culture of the intelligence services. It is noteworthy that Soeharto's people filled ABRI and all intelligence agencies, remaining de facto loyal to the former rather than the new ruler. The only option was to put "trustworthy people" in the lead. At BAKIN, president BJ Habibie, who replaced Suharto, chose Lieutenant General ZA Maulani. President Abdurrahman Wahid, who was elected in 1999, appointed Lieutenant General Arie J Kumaat (some sources state that he was 'forced' to appoint Arie because there was no other loyal figure capable of controlling BIN - still dominated by military elements). President Megawati Soekarnoputri, elected in 2001, appointed Lieutenant General AM Hendropriyono. BAKIN then changed its name to BIN, with the main functions and tasks stipulated in Presidential Decree Number 103 of 2001.

The positions of head of BIN tend to be political rather than professional ones. The tradition of choosing a President's confidant continued during the days of President Susilo Bambang Yudhoyono (SBY) and President Joko Widodo (Jokowi), who had also elected former high-ranking police officers. President SBY appointed Major General Syamsir Siregar, ${ }^{27}$ General (Police) Sutanto, and Lieutenant General Marciano Norman. Meanwhile, President Jokowi appointed senior retired officers, Lieutenant General Sutiyoso and General (Police) Budi Gunawan - who are currently still in office.

As stated above, Suharto's rule, which fell due to various pressures, ${ }^{28}$ left one problem for the new government; military structures that were still loyal to Suharto. ZA Maulani, who was the head of BAKIN under President Habibie, in an interview in the media expressed Soeharto's disappointment with the civilian elite who 'betrayed' him by quoting Suharto's statement, "I have nurtured and promoted them since the beginning of their career but when I really needed their

27 The last rank of Siregar before retirement was Major General with the post of Head of BIA. He was appointed after retirement so that he did not get a promotion.

28 Sukardi Rinakit mentioned several factors that caused Suharto's fall, including: 1). International political pressure, especially from the United States and the IMF. This pressure uses the issue of human rights violations, the kidnapping of activists and the continuing violence in Aceh, Timorleste and Papua. This pressure also led to a worsening economic situation; 2). The elite conspiracy, especially the ICMI leadership, which withdrew support, mobilized demonstrations and urged the leadership of the Majelis Permusyawaratan Rakyat (People's Consultative Assembly, MPR) to ask Soeharto to resign; 3 ). A shift in support within the military, especially from 'red-white' (nationalist as symbolized by the colour of Indonesian flag) to 'green' (close to Islamic political groups) military lines. In an extreme way, this situation is referred to as the contestation between the factions of "Political Islam" and "Pancasila" which led to the May 1998 riots that took place a few days before Soeharto stepped down. See Sukardi Rinakit, The Indonesian Military After the New Order (ISEAS, 2005), 3-4. 
support, they rejected me." 29 The change of attitude of the army, loyal to Suharto, to find a mechanism to reform the security sector, involving the military, police, and intelligence, could only be gradual and full of compromises, without completely alienating them from the practical political space and state policymaking, which in fact was the authority of the civilian political authority.

BAKIN, which later became BIN, is still under the scrutiny of the military, especially concerning their alleged connection to a number of social conflicts and violent acts that occurred after 1998, seen as a reflection of Soeharto's 'anger.' There are three views formed at this time. First, the accusation that all forms of chaos were caused by operations in loyalty to the Orde Baru, carried out widely and systematically with massive and terrible effects. Second, although the pressure of the new government on the security apparatus to overcome this security disturbance has strengthened, the actions taken have been slow and sub-optimal. ${ }^{30}$ There are allegations of deliberate failure to deal with this chaos properly, again rooting in loyalty to the Orde Baru. The third view states that this chaos is a strategy of consolidating security actors to test their position in the eyes of the civilian government, and when the civilian government asks for action by the apparatus, then there is a negotiation regarding the weight of pressure for reform and what 'may' or 'should not' be carried out.

Efforts to promote intelligence accountability are not an easy matter. The case of the death of human rights activist Munir Said Thalib ${ }^{31}$ on a flight from

29 Rinakit, The Indonesian Military After the New Order, 5.

30 During the reign of President Abdurrahman Wahid, conflicts over ethnic issues in Kalimantan and religious issues in Maluku occurred. My experience of being part of one of the palace's information sources at that time shows that the President lacked the support of valid information from the field, was unable to control military manoeuvers that worsened the conflict by turning it into a business arena, and failed to maximize the effect of intelligence operations for prevention and creation of normal conditions. The image of the President as a defender of religious and ethnic minorities, able to orchestrate reform, was 'thwarted' by the machines in the government organizations at that time. One monumental example is the entry of Laskar Jihad, a paramilitary group led by alumni of the Afghanistan war, to Maluku to participate in conflicts over religious issues. The president firmly ordered all security and intelligence apparatus to prevent their entry, but there was no maximum effort, even allegations emerged that they were deliberately given space to attend. In the end, Maluku conflict became one of the entry points for the Jemaah Islamiyah and alQaeda terrorism movements, a training camp and recruitment of new cells and networks, and thus sow the seeds of radical movements and terrorism that lived and spread in Indonesia to this day.

31 Munir Said Thalib is an idealistic human rights activist who defends victims of violations and is willing to confront the military and police to fight for the rights of these victims. Threats of murder and intimidation to force Munir to stop his activities while leading KontraS and Imparsial (the two strongest human rights advocacy organizations in Indonesia founded by him) are nothing new, including monitoring and attempts to thwart his defense activities carried out by elements of the security forces directly or indirectly. Before leaving for Amsterdam, Munir admitted he received a phone call and a request from the 'agent' (who was later determined, based on the 
Indonesia to Amsterdam on September 7, 2004-a suspected "intelligence operation" after the 1998 reforms - is deadlocked. The legal process only tried one field actor, who was said to be "an intelligence agent" and found him guilty, and one official at the leadership level of BIN who communicated with the agent but was eventually acquitted. To date, there has been no new progress in law enforcement in this case, and the issue and allegations of intelligence operations remain a mystery. This case adds to a series of data on attacking and silencing opposition groups and human rights defenders that should not have happened during the reform era. Such cases raise the awareness that the posture of new intelligence institutions and operations will not be possible if we refer to the organizational realities and existing legal basis because they are a product of the authoritarian politics of the Orde Baru. What should be worrying is not the new rules promoted but the current absence of norms of democratic oversight over intelligence.

The State Intelligence Law was finally issued at the end of 2011, 12 years after the reform started. This law, adopted as a result, among other reasons, of the pressure after the murder of human rights activist Munir, is indeed forward-oriented and may contribute to the success of intelligence reform, preventing the repetition and tradition of authoritarian intelligence in the style of the Orde Baru. Intelligence services should abandon the old paradigm in understanding threats and pay close attention to new challenges such as global terrorism. Sectarian politics need to be strengthened at home. Intelligence should contribute to creating a peaceful world free from new threats such as environmental damage and disease outbreaks.

\section{Legislation, State Intelligence Governance, and Intelligence Reform}

Since the beginning of the 1998 reforms, the pressure from civil society to carry out intelligence reform was not strong enough. Apart from the structural political change such as democratic elections and amendments or cancellation of articles of the constitution and authoritarian legislation, the main security sector issues were only marginally addressed. Security sector reform started with separating the two institutions previously part of ABRI - the Tentara Nasional Indonesia (Indonesian National Army, TNI) and the Kepolisian Negara Republik Indonesia (Indonesian National Police, Polri). Other key issues were the human rights violations during the Orde Baru era, revocation of ABRI's dual function, the release of the Orde Baru political prisoners, and post-1997 economic recovery. ${ }^{32}$

results of the police investigation, to be the perpetrator) for a meeting on the JakartaSingapore flight, before continuing to Amsterdam. This information has been conveyed directly by Munir to his family and friends before he died.

32 To understand the dynamics of the civil society movement in pushing for security sector reform, especially reform of the military, police and intelligence in Indonesia in the 1998-2006 period, see Mufti Makarim A. and Sri Yunanto, eds., Efektivitas Strategi Organisasi Masyarakat Sipil Dalam Advokasi Reformasi Sektor Keamanan di Indonesia 
Pacivis UI underlined the challenges of avoiding security disruption and conflict, which made the civilian elite 'compromise' not to put too much pressure on the military because they were needed to restore security. This need for the 'military' was seen in the appointment of military officers such as ZA Maulani, Arie Kumaat, and AM Hendropriyono as heads of BAKIN (which later became BIN). ${ }^{33}$ At that time, Aceh, Timor-Leste, and Papua presented a serious threat of separatism, and social conflicts with religious and ethnic backgrounds emerged in Maluku, Sulawesi, and Kalimantan.

In the Soekarno era, the challenge for the intelligence organization was with the BKI coordination system at the level of institutional leadership (such as the Head of the Attorney General's Office and the Military Leadership) who were not active in technical coordination activities. In practice, leaders often appoint officials not competent to make direct decisions or of low rank. As a result, BKI, which was established based on Government Regulation no. 64 of 1958, was only less than a year old. President Soekarno then formed BPI through Government Regulation no. 8 of 1959 and gave it not only coordination authority but also the right to conduct intelligence operations. Subandrio, as Head of BPI and concurrently Deputy Prime Minister One (with a 'rank' equivalent to a four-star officer) and the Minister of Foreign Affairs, was expected to exercise effective control over the internal intelligence. However, after the September 30 incident, Subandrio was removed from his position and tried, while the BPI was changed to KIN by President Sukarno with the leadership of Major General Soeharto ${ }^{34}$ (who later 'overthrew' Soekarno). KIN was then stipulated based on Keputusan Presiden (Presidential Decree) number 181 of 1966, which was later changed to BAKIN based on Keputusan Presiden number 70 of 1967.

Like BPI, BAKIN does not only coordinate intelligence agencies in the ministry and the military but also conducts intelligence operations. The change to BIN, which was initially regulated based on Keputusan Presiden number 5 of 2002, was also accompanied by a mandate to continue with the same authority. As on previous occasions, building an effective BIN faced certain difficulties, e.g., the rivalry among the departmental intelligence agencies. Furthermore, its institutional status was weak - whereas BIN is only based on a Keputusan Presiden, the institutions and ministries that must be coordinated are formed based on a Law so that their position is 'higher.' 35

The process of drafting the law on intelligence proposed in the 1998 reform package was callous. There were pros and cons regarding the need for this law, and the draft proposed by the government was heavily criticized. Still, the draft

1998-2006 (The Effectiveness of the Strategy of Civil Society Organizations in Advocating for Security Sector Reform in Indonesia 1998-2006) (IDSPS, 2008).

33 Widjajanto and Wardhani, State-Intelligence Interaction, 93.

34 See Irawan Sukarno, Aku 'Tiada' Aku Niscaya Menyingkap Lapis Kabut Intelijen (I 'unexist' [but] I Undoubtedly Unveil the Fog of Intelligence) (Yayasan Pustaka Obor Indonesia, 2011), 53-55.

35 Sukarno, Aku 'Tiada' Aku Niscaya Menyingkap Lapis Kabut Intelijen, 57-59. 
provided the law enforcement authority to intelligence apparatus with exclusive powers in civilian strategic intelligence operations. It lacked, however, provisions for intelligence accountability and professionalism. For civil society, the draft submitted for discussion in parliament would have the same legitimacy as intelligence organizations and operations undertaken under authoritarian rule.

Fortunately, during discussions at the DPR, there were changes and improvements, although not all of them had become more moderate and accommodated proposals by NGOs. Matters that still needed to be improved when this law was passed were then challenged in the Constitutional Court. And even though, in the end, civil society 'lost' in this judicial review lawsuit, this example shows the hope of contributing to the creation of intelligence that is in line with the principles of democracy and the rule of law adopted by Indonesia. With the existence of this Law, intelligence posture, organization and operations are reflected and can be monitored by the public and parliament. The task that awaits in the future is to supervise the implementation of this legislation, including evaluating the reform process of BIN and intelligence organizations at the ministerial and institutional level (including in the military and police) so that they work in compliance with existing legal provisions.

\section{Closing: Actual Challenges of Indonesian Intelligence}

From 1945 to the present, the state intelligence organization has changed its 'official' name six times, namely BRANI (Indonesian State Secret Agency), BKI (Intelligence Coordinating Agency), BPI (Central Intelligence Agency), KIN (National Intelligence Command), BAKIN (National Intelligence Coordinating Agency), and BIN (State Intelligence Agency). The idea of a change was carried out with the aim of improving and strengthening this organization. However, our history proves that this is not easy.

Intelligence as the "first line of battle" requires adaptation to the times and threats. The orientation in institutional development is on the improvement that synergizes five aspects; democracy and the principles of the rule of law, professionalism, adaptation to technological developments, the ability to read contemporary threats, and transformation of the capabilities provided by the state to get maximum results.

Irawan Sukarno conveyed an interesting view that (Indonesian) intelligence in the future should aim to win the peace. The administration of intelligence becomes more complex as unconventional battlefields emerge, which are much more challenging than conventional ones. Unconventional warfare has more complex dimensions, strategies, dynamics, risks, and ranges; it cannot be faced with just armed military forces but requires "civilian forces" tailored to the type of battle being faced. ${ }^{36}$

In conclusion, we want to underline three main issues. First, the experience of the militarization of intelligence and the use of intelligence organizations for

36 Sukarno, Aku 'Tiada' Aku Niscaya Menyingkap Lapis Kabut Intelijen, 208-210. 
the benefit of the elite should serve as a lesson for the restructuring and reform of intelligence into a professional agency, independent from politics and serving the interests of the state solely. Second, the temptation to return to an operating posture and a domestically oriented threat view, especially to 'attack' political opposition and control the public, should be resisted. It has bad precedents and will never help form a modern intelligence organization. And third, the challenges faced by Indonesia, including the Covid-19 pandemic currently sweeping the world, should be used to prove the resilience of intelligence work. The image of "Intel Melayu" (an intelligence agent who only can frighten the public by showing their identities) still attached to our intelligence agents should change. When this happens, then the public concern about the President's status as a single user of BIN and the politicization of this organization will be out of place.

\section{Disclaimer}

The views expressed are solely those of the author and do not represent official views of the PfP Consortium of Defense Academies and Security Studies Institutes, participating organizations, or the Consortium's editors.

\section{Acknowledgment}

Connections: The Quarterly Journal, Vol. 20, 2021, is supported by the United States government.

\section{About the Author}

Mufti Makarim A. is an expert on Politics, Defense, and Security at the Executive Office of The President of the Republic of Indonesia since January 2020. Previously, apart from his position as a researcher and consultant on defense and security issues, Mufti conducted advocacy, research, and empowerment of civil society organizations on security sector reform, conflict studies, human rights, and counter-terrorism. He was involved with KontraS (The Commission for the Disappearances and Victims of Violence) in 1999-2007 and IDSPS (The Institute for Defense, Security and Peace Studies) in 2007-2013 - the time when Indonesia's CSOs left a mark on reforming security actors-including the intelligence-as well as the civilian authority as part of Indonesia's democratization and reformation. After 2013, Mufti focused on his professional consultancy and research for the government, non-government and private sectors.

E-mail: makarimalahlaq@gmail.com 